\title{
Anatomy of parotid gland and its secretory ducts in sheep
}

\author{
G.B. Uzun'10, B. Kamaşak²®, T. Ulcay²®, K. Aycan²® \\ ${ }^{1}$ Department of Medical Laboratory Services, Vocational School of Health Services, \\ Malatya Turgut Özal University, Malatya, Turkey \\ 2Department of Anatomy, Faculty of Medicine, Kırşehir Ahi Evran University, Kırşehir, Turkey \\ [Received: 5 May 2021; Accepted: 1 July 2021; Early publication date: 21 July 2021]
}

Background: The parotid gland in sheep ends freely in front of the masseter muscle, and paracondylary section of occipital bone and extends deep until pterygoid extends of sphenoid bone and hyoid bone. The structure of salivary glands in mammals has been thoroughly studied using histological and sialographic method. This study aimed to reveal the detailed anatomic features and race-specific differences of the canal system of the parotid glands in Akkaraman sheep by using the corrosion cast technique.

Materials and methods: Thirteen sheep parotid glands from 7 Akkaraman sheep were used in this study. Parotid glands were removed from their places with ducts. Measurements were made with a calliper from back to front, top to bottom and inside to outside. After dissection of the parotid glands, their volumes were measured according to the 'Archimedes principle'. Also, 13 sheep parotid glands were examined using the polyester resin method.

Results: In the present study, our average metric results were: length of parotid duct was $10.92 \pm 1.027 \mathrm{~cm}$, length of parotid gland was $5.87 \pm 1.04 \mathrm{~cm}$, volume of parotid gland was $12.50 \pm 2.48 \mathrm{~cm}^{3}$, thickness of parotid gland was $0.75 \pm$ $\pm 0.36 \mathrm{~cm}$ and width of parotid gland was $4.07 \pm 0.43 \mathrm{~cm}$. The average weight of the parotid gland of Akkaraman sheep was identified as $25.3 \mathrm{~g}$. Accessory parotid gland was not encountered in the current study.

Conclusions: It was observed that polyester entered into the parotid duct and filled up until the acinus and made both acinus and secretory ducts well-examined in this study. It was also observed that the parotid gland consisted of lobes and lobules. The average number of lobes was 12. The number of lobules in a lobe varied between 3 and 16, each lobe consisted of an average of 9 lobules. It was found that each lobe has its own lobar duct. (Folia Morphol 2022; 81, 3: 679-684)

Key words: parotid gland, corrosion, secretory duct

\section{INTRODUCTION}

The salivary glands play an important role in the ruminants and are classified as major and minor. In ruminants, the major salivary glands are parotid, submandibular, and sublingual, while minor salivary glands are buccal and labial $[16,21]$. Their secretion, saliva, is serous and mucous in character, and is produced in large quantities, e.g. the amount of saliva

Address for correspondence: B. Kamaşak, R.A., Department of Anatomy, Faculty of Medicine, Kırşehir Ahi Evran University, Kırşehir, Turkey, tel: +90545 28289 02, e-mail: brc1608@hotmail.com

This article is available in open access under Creative Common Attribution-Non-Commercial-No Derivatives 4.0 International (CC BY-NC-ND 4.0) license, allowing to download articles and share them with others as long as they credit the authors and the publisher, but without permission to change them in any way or use them commercially. 
secreted during a 24 hour period in sheep is $1-4 \mathrm{~L}$ [6] or 6-16 L [10, 22].

Histologically parotid salivary gland is usually a serous gland in all domestic animals, man and rodents; a few mucous cells or adenomeres may be present in carnivores $[6,10,22]$.

The parotid gland, the largest salivary gland in sheep, is situated on the masseter muscle along the caudal border of the vertical ramus of the mandible from the zygomatic arch to the angle of the junction of the linguo-facial and maxillary veins and is located at the base of the ear between the back side of ramus mandibulae and transvers process of atlas.

The parotid duct leaves the gland at its ventral and rostral surface, coursing along the ventral and rostral border of the masseter muscle, as it is located between the muscle and the facial vein. It enters the oral cavity and opens into the papilla salivalis opposite to the upper second molar tooth $[9,15,22]$.

Human parotid glands are the largest major glands (average weight: $25-30 \mathrm{~g}$ ) located on each side of the head, behind the external auditory canal of the mandible and the skull base. The development of human parotid glands starts from the $5^{\text {th }}$ and $6^{\text {th }}$ week of the intrauterine stage. The main excretory duct of the parotid gland is Stensen's duct; it runs through the anterolateral edge of the gland over the masseter muscle, culminating at the buccal mucosa in the upper molar region. Parotid glands are exclusively formed by serous acini $[2,19]$.

Although the duct of the parotid gland is usually one, it can vary numerically. For example, a 46-year-old man has a double parotid canal on the right side of his face $[1,12,13]$. Sometimes an accessory parotid gland is found anterolaterally to the masseter muscle in humans [5].

The mass of the mandibular and parotid gland was reported to be $9.0 \mathrm{~g}$ and $11.0 \mathrm{~g}$, respectively, in sheep $[14,22,24]$. In another study the mass of mandibular and parotid gland in sheep was reported to be $16.2 \pm 4.6 \mathrm{~g}$ and $13.5 \pm 2.6 \mathrm{~g}$ [7]. The mean length of the parotid gland was $6.04 \pm 0.48 \mathrm{~cm}$ in sheep and $6.56 \pm 0.361 \mathrm{~cm}$ in goat [18], and $3.96 \pm$ $\pm 0.26 \mathrm{~cm}$ in dog [11]. Human parotid glands average weight is $25-30 \mathrm{~g}$ [19] and 14-28 $\mathrm{g}$ [25].

The mean diameters of mandibular and parotid ducts were $1.4 \pm 0.3 \mathrm{~mm}$ and $3.1 \pm 1.0 \mathrm{~mm}$, respectively, in sheep [7]. The parotid duct measured about $20 \pm 0.41 \mathrm{~cm}$ in length and $0.5 \pm 0.2 \mathrm{~cm}$ in diameter in camel (Camelus dromedarius) [15]. Estecondo et al. [11] showed that in Zaedyus pichiy, the submandibular gland consists of 2 lobes.

The parotid gland was irregular rectangular and had five processes. Both the parotid and the mandibular salivary glands could be divided into 4 segments [15].

The normal sheep mandibular and parotid salivary glands have a multilobular appearance in cadaver heads [7]. Sheep parotid gland was made up of 4 lobes (cranial, middle, caudal and accessory) and the main excretory duct was formed from union of 4 lobar ducts [20]. Human parotid gland is divided into superficial and deep lobes [25]. The duct system of the major salivary glands is starting from the acini, the intercalary duct, the intralobular duct (striated duct) (secretory tubule), the interlobular duct, the lobular duct, the intralobar duct and the (excretory duct) ductus parotideus, $[2,6,8,13,23]$.

The structure of salivary glands in mammals has been thoroughly studied using histological, histochemical, and sialographic method $[7,10,11,18,24]$.

However, there is no study on parotid ductal system in human and other animals with corrosion method. This study aimed to reveal the detailed anatomic features and race-specific differences of the canal system of the parotid glands in Akkaraman sheep by using the corrosion cast technique.

\section{MATERIALS AND METHODS}

Thirteen sheep parotid glands from 7 Akkaraman sheep (12-23 months old and 34-45 kg) were used in this study. We used 7 sheep in our study, but since the ducts of one of the parotid glands could not be removed to be examined under a microscope, we expressed it as 13 parotid glands.

Parotid glands were removed from their places with ducts (Fig. 1). Measurements were made with a calliper from back to front (length), top to bottom (length-height) and inside to outside (thickness). Course of parotid duct and length from the entrance of mouth to the gland were also measured. After dissection of the parotid glands, their volumes were measured according to the 'Archimedes principle'. For this reason, the parotid gland was placed into a measured container filled with physiological saline solution and the volume of the parotid gland was measured by determining the amount of water overflowed from the container. This process was repeated 6 times and the average was taken as the volume of the gland. 


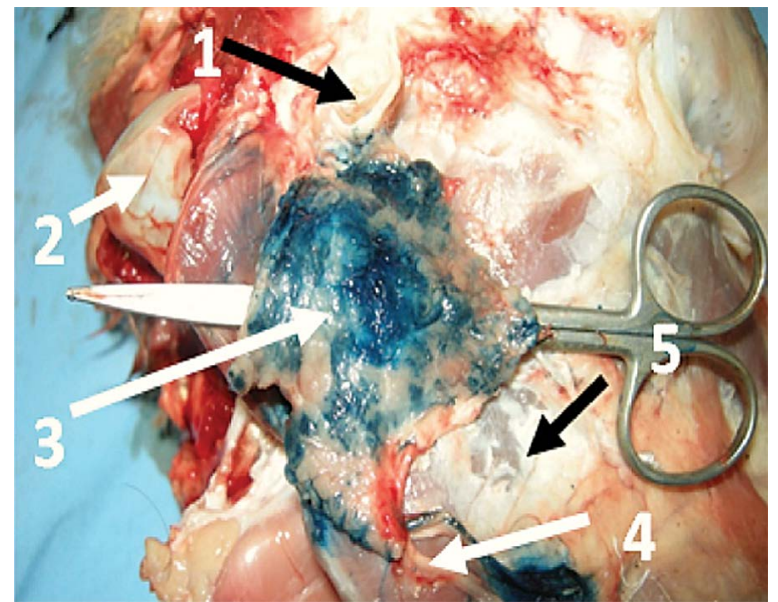

Figure 1. Head of sheep; 1 - external ear canal; 2 - occipital condyle; 3 - parotid gland; 4 - parotid duct; 5 - masseter muscle.

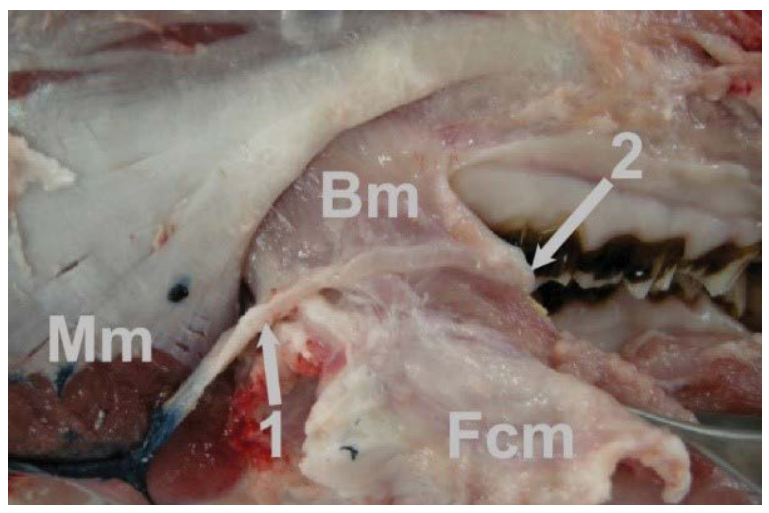

Figure 2. The course of parotid duct; 1 - ductus parotideus; 2 - papilla parotidea; $\mathrm{Mm}$ - masseter muscle; $\mathrm{Bm}$ - buccinator muscle; $\mathrm{Fcm}$ - facial muscle.

Table 1. Measurement values of parotid glands in Akkaraman sheep

\begin{tabular}{lcccc}
\hline Parameters & Right parotid gland & Left parotid gland & Min-Max & Total \\
\hline Length of parotid gland $[\mathrm{cm}]$ & $6.0 \pm 0.2$ & $5.7 \pm 1.7$ & $4.5-7.0$ & $5.87 \pm 1.04$ \\
Thickness of parotid gland $[\mathrm{cm}]$ & $0.9 \pm 0.4$ & $0.5 \pm 0.7$ & $0.5-1.30$ & $0.75 \pm 0.36$ \\
Width of parotid gland $[\mathrm{cm}]$ & $4.4 \pm 0.1$ & $3.7 \pm 0.3$ & $3.50-4.50$ & $4.07 \pm 0.43$ \\
Volume of parotid gland $\left[\mathrm{cm}{ }^{3}\right]$ & $14.5 \pm 0.7$ & $10.5 \pm 1.4$ & $9.50-15$ & $12.50 \pm 2.48$ \\
Length of parotid duct $[\mathrm{cm}]$ & $11.75 \pm 0.35$ & $10.1 \pm 0.5$ & $9.70-12$ & $10.92 \pm 1.027$ \\
\hline
\end{tabular}

Data are shown as mean \pm standard deviation or minimum-maximum (Min-Max).

Ten millilitres physiological saline containing $2 \%$ heparin was injected into the parotid duct after cleaning the tissues surrounding the parotid gland. In order to show the duct system of parotid gland, $15 \mathrm{~mL}$ of the polyester resin solution was injected into parotid duct with a $120 \mathrm{mmHg}$ pressure. Twenty-four hours passed for the solidification of the polyester solution. The parotid gland was put into a $37 \% \mathrm{HCL}$ solution for 24 hours. Parotid gland tissues that were dissolved were washed under tap water and air-dried. With the use of a stereomicroscope, ducts of parotid gland were dissected with a forceps from the parotid gland $[3,4]$.

\section{RESULTS}

Present findings revealed that parotid gland of the sheep was located on the masseter muscle and settled outside the mandibula. Accessory parotid gland was not encountered in the present study. Parotid duct was separated from the gland at the level of angulus mandibulae. It was $2 \mathrm{~cm}$ above the inferior margin of mandibula and was extended parallel to this edge on the masseter muscle. After crossing the front edge of the masseter muscle, it run on the buccinator muscle. When it reached the upper edge of buccinator muscle, it opened into the mouth through parotid papilla between the top $3^{\text {rd }}$ premolar and the $1^{\text {st }}$ molar maxillary teeth (Fig. 2).

In the present study, our metric results were shown in Table 1. The average weight of the parotid gland of Akkaraman sheep was identified as $25.3 \mathrm{~g}$.

It was observed that polyester entered into the parotid duct and filled up until the acinus and made both acinus and secretion canals well-examined in this study.

Usually, parotid duct was initially formed by the combination of 2 interlobar duct, then the thickness or diameter of parotid duct increased with the number of canals participating in its formation. Parotid duct was formed by combining lobar ducts coming out of the lobes in the gland (Fig. 3). Every lobe of the parotid gland had a lobar duct, each lobar duct converged with each other to create the parotid duct.

It was also observed that the parotid gland consisted of lobes and lobules. The number of lobes of parotid glands varied from one gland to another. The average number of lobes was 12 . The number of lobules in a lobe varied between 3 and 16, each lobe consisted of an average of 9 lobules. It was found 


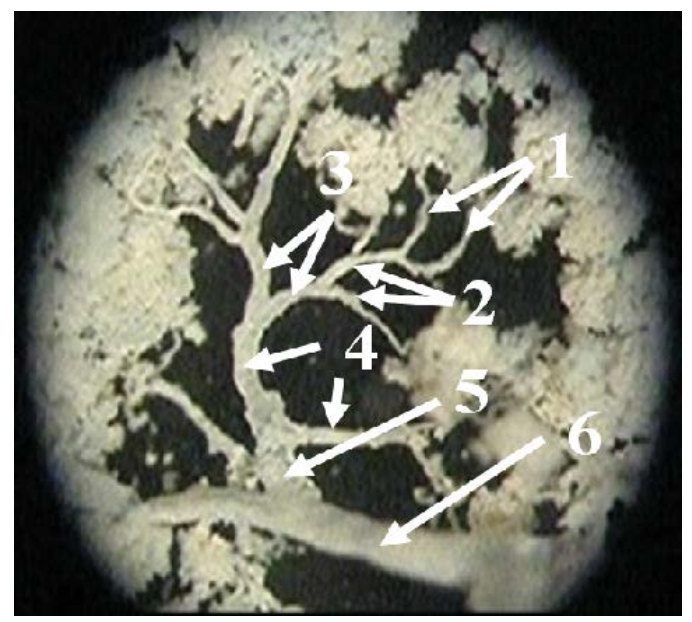

Figure 3. Ducts of a lobe and lobules in the parotid gland; $1-$ intralobular duct; (striated duct); 2 - interlobular duct; 3 - lobular duct; 4 - intralobar duct; 5 - lobar duct; 6 - excretory duct (parotid duct).

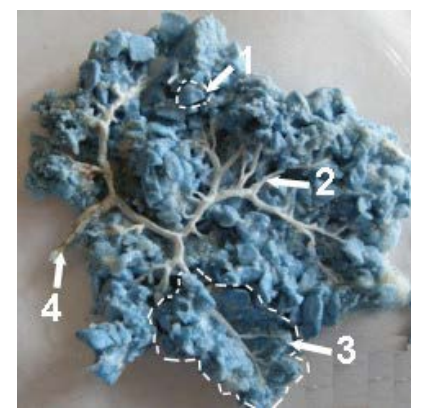

Figure 4. Structure of a parotid gland; 1 - lobule; 2 - interlobular duct; 3 - lobe; 4 - parotid duct.

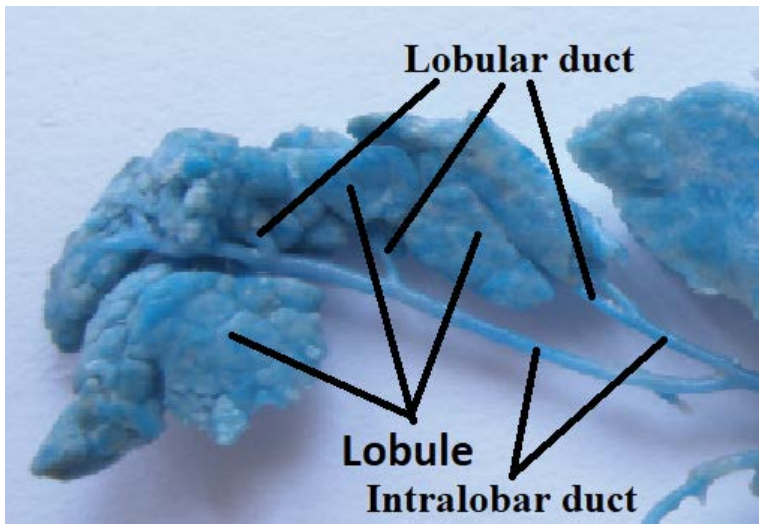

Figure 5. Lobules of a lobe in parotid gland.

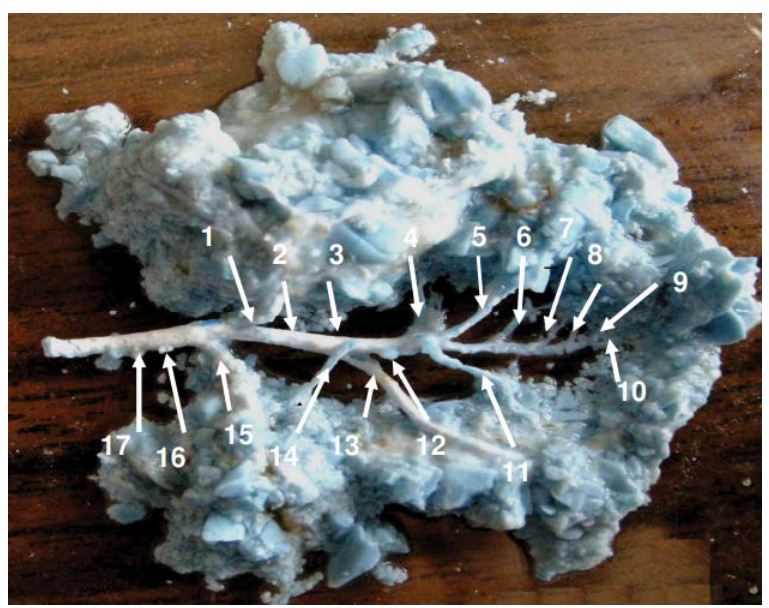

Figure 6. Lobar duct (1-17), excretory duct (parotid duct) in parotid gland.
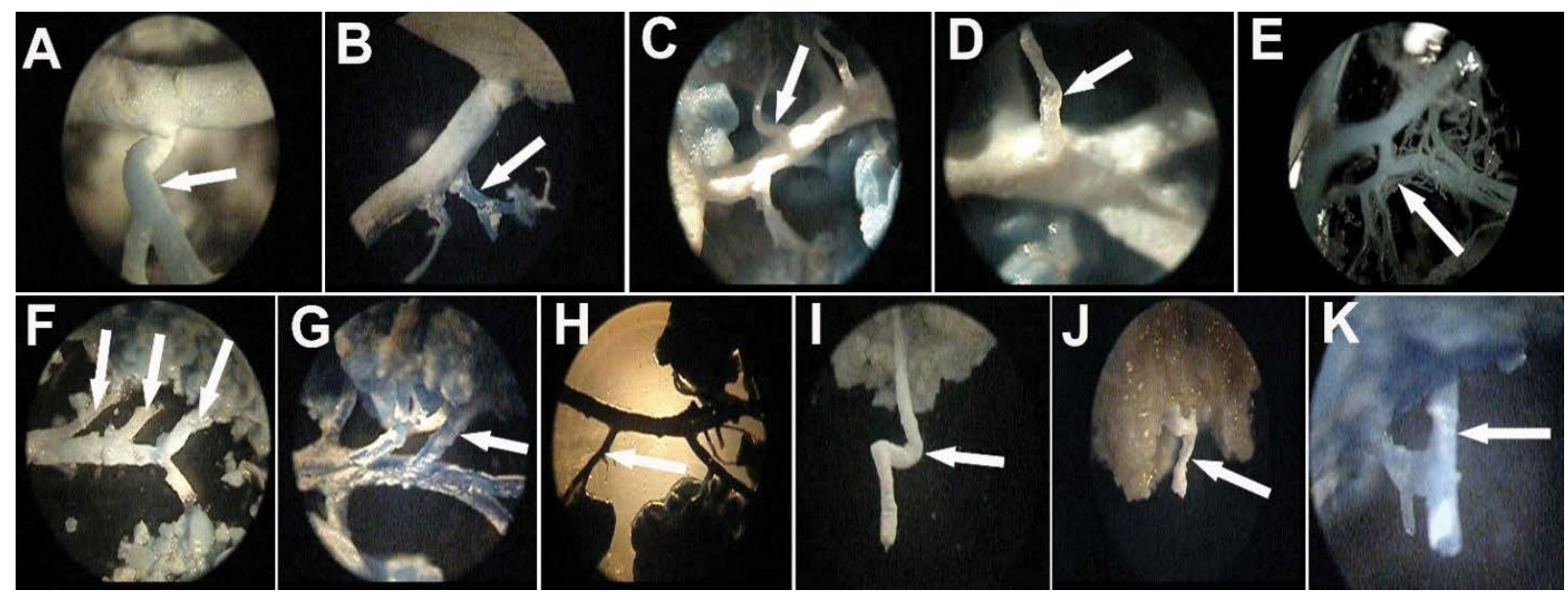

Figure 7. A-K. Connections (arrow) of ductus of parotid gland in sheep.

that each lobe had its own lobar duct (Figs. 3-6). Secretory pathways were clearly shown in parotid gland in our corrosion cast technique.
In this study, ductal connections of small-diameter ducts and large-diameter ducts were found in seven types (Fig. 7). 
Accordingly:

- $23.08 \%$ of ducts formed slight curvatures at this connections (Fig. 7A, C, D);

- $7.69 \%$ of ducts connected other ducts at a right angle (Fig. 7B);

- $15.38 \%$ of ducts connected other duct at different angles (Fig. 7G, H);

- $7.69 \%$ of minor ducts connected initially with each other at the same direction, then connected with major ducts (Fig. 7E);

- $7.69 \%$ of minor and major ducts connections usually occurred after the combination of 2 ducts coming here at different angles (Fig. 7A);

- $7.69 \%$ of minor duct merged into the major ducts at the same angle, which paralleled to each other (Fig. 7F);

- $23.08 \%$ of the interlobar ducts exited the lobar duct without curvature, while the others came out with a curvature (Fig. 7I, J, K).

In our study, we did not statistically analyse the ductal connections of the parotid ducts. For this reason, we did not express it as a percentage.

\section{DISCUSSION}

We examined macroscopically parotid gland, parotid duct and microscopically ductal system of parotid gland in the current study.

The parotid gland is located on the lateral surface of the masseter muscle and surrounded back side of this muscle. It goes deep and is directly neighbouring ramus mandibulae. The upper part of the parotid gland is closed by the outer ear, and the paracondylar part by the caudal of the occipital bone. It extends deep until the pterygoid process of the sphenoid bone and the hyoid bone (Fig. 2).

Sometimes an accessory parotid gland is found anterolateral to the masseter muscle in humans [5], but accessory parotid gland was not encountered in the present study in sheep heads.

Some investigation indicated that parotid duct enters the oral cavity opposite to the upper second molar tooth in the sheep $[9,15,22]$. But our study shows parotid duct opens into the mouth through parotid papilla between the top $3^{\text {rd }}$ premolar and the $1^{\text {st }}$ molar maxillary teeth (Fig. 2).

Parotid gland has a parotid duct in animals, but double parotid duct was observed in a human patients, in the right aspect of the face of a 46-year-old man [1, 12, 13]. Double parotid duct was not found in our study.
In the literature, the mean length of the parotid gland of sheep was $6.04 \pm 0.48 \mathrm{~cm}$ and $6.56 \pm$ $\pm 0.361 \mathrm{~cm}$ in goat [18] and $3.96 \pm 0.26 \mathrm{~cm}$ in dog [11] In our study, the average length of the parotid gland in sheep was identified as $5.87 \pm 1.04 \mathrm{~cm}$ (Table 1).

The length and diameter of the parotid duct in the camel were reported as $20 \pm 0.41 \mathrm{~cm}$ and $0.5 \pm$ $\pm 0.2 \mathrm{~cm}$, respectively (Camelus dromedarius) [15]. The mean diameter of mandibular and parotid duct were $1.4 \pm 0.3 \mathrm{~mm}$ and $3.1 \pm 1.0 \mathrm{~mm}$, respectively, in sheep [7]. Average length of parotid duct was $10.92 \pm 1.027 \mathrm{~cm}$ in our study (Table 1 ).

The mass of the mandibular and parotid gland was reported to be $9.0 \mathrm{~g}$ and $11.0 \mathrm{~g}$, respectively, in sheep [14, 22, 24]. In another study the mass of mandibular and parotid gland in sheep was reported to be $16.2 \pm 4.6 \mathrm{~g}$ and $13.5 \pm 2.6 \mathrm{~g}$, respectively [7] Human parotid glands' average weight was reported as $14-30 \mathrm{~g}[19,25]$. The average weight of the parotid gland of Akkaraman sheep was identified as $25.3 \mathrm{~g}$ in the current study (Table 1).

In our study, some parameters of the parotid gland, such as volume, thickness and width, which were not previously reported in the literature, were also measured. We found the average volume of the gland as $12.50 \pm 2.48 \mathrm{~cm}^{3}$, the average thickness as $0.75 \pm 0.36 \mathrm{~cm}$ and the average width as $4.07 \pm$ $\pm 0.43 \mathrm{~cm}$ (Table 1).

Parotid gland consists of lobes and lobules. The number of lobes of the parotid glands can vary from one gland to another. The number of lobes in the parotid gland is related to the number of ducts [17], and some studies have shown that the mandibular gland consists of 2 lobes [11]. Both parotid and mandibular salivary glands can be divided into 4 sections [15]. While sheep mandibular and parotid salivary glands have a multilobular appearance [7], the human parotid gland is divided into superficial and deep lobes [25]. The sheep parotid gland consists of 4 lobes: cranial, middle, caudal and accessory [20]. The present study showed that the parotid duct is divided into lobar ducts and each lobar duct represents one lobe, and in this context, the average number of lobes in the parotid gland is 12 . Also, lobar duct is divided into lobular ducts, each lobe consists of an average of 9 lobules (Figs. 3-6). We believe that our research will be useful in studies on the ductal system of the parotid gland. 


\section{CONCLUSIONS}

The structure of the salivary glands in mammals has been studied in depth by histological, histochemical, and sialographic method. Polyester injection and corrosion method shows the ductal anatomy of the salivary glands very well. However, there is no study about the corrosion method and parotid ductal system in mammals. Therefore, this study was conducted to define the histological and anatomical features of the adult sheep parotid acini and ductal system in this method. In this study, it was observed that the polyester entered the parotid duct and filled up to the acini and examined both the acinus and secretion channels well.

\section{Conflict of interest: None declared}

\section{REFERENCES}

1. Aktan ZA, Bilge O, Pinar YA, et al. Duplication of the parotid duct: a previously unreported anomaly. Surg Radiol Anat. 2001; 23(5): 353-354, doi: 10.1007/s00276-0010353-y, indexed in Pubmed: 11824138.

2. Amano O, Mizobe K, Bando $Y$, et al. Anatomy and histology of rodent and human major salivary glands. Acta Histochem Cytochem. 2012; 45(5): 241-250, doi: 10.1267/ ahc. 12013.

3. Aycan K, Bilge A. Plastik enjeksiyon ve korozyon metodu ile vasküler sistem anatomisinin araştırılması. Erciyes Üniv Tıp Fak Dergisi. 1984; 6: 545-552.

4. Aycan K, Ulcay T, Kamaşak B. The morphology of the afferent and efferent domain of the sheep glomerulus. Folia Morphol. 2021; 80(4): 881-887, doi: 10.5603/ FM.a2020.0124, indexed in Pubmed: 33084008.

5. Bahadir O, Bektas D, Caylan R, et al. Sialolithiasis of an accessory parotid gland. Ann Otol Rhinol Laryngol. 2004; 113(1): 52-54, doi: 10.1177/000348940411300112, indexed in Pubmed: 14763574.

6. Banks JW. Applied Veterinary Histology. 2nd ed. Williams and Wilkins, Baltimore 1986: 417-418.

7. Dehghani SN, Tadjalli M, Masoumzadeh MH. Sialography of sheep parotid and mandibular salivary glands. Res Vet Sci. 2000; 68(1): 3-7, doi: 10.1053/rvsc.1999.0318, indexed in Pubmed: 10684751.

8. Dellmann HD, Brown EM. Textbook of veterinary histology. 2nd ed. Lea Febiger, Philadelphia 1981.

9. Dursun N. Veteriner Anatomi. Medisan Yayınevi, Ankara 2006: 31-35.

10. Elewa $\mathrm{YH}$, Bareedy MH, Abuel-Atta AA, et al. Structural characteristics of goat (Capra hircus) parotid salivary glands. Jpn J Vet Res. 2010; 58(2): 121-135, indexed in Pubmed: 20715422.
11. Estecondo S, Codón S, Casanave E. Histological study of the salivary glands in Zaedyus pichiy (Mammalia, Xenarthra, Dasypodidae). Int J Morphol. 2005; 23(1), doi: 10.4067/s0717-95022005000100004.

12. Fernandes $A$, Lima R, Rossi $M$, et al. Parotid Gland with Double Duct: An Anatomic Variation Description. Int J Morphol. 2009; 27(1), doi: 10.4067/s071795022009000100023.

13. Gartner PL. Essentials of Oral Histology and Embryology. 3nd ed. Jen House, publishing company, Baltimore 1999: 127-135.

14. Getty R. Sisson and Grossman's the anatomy of domestic animals. 5th ed. WB Saunders Co, Philadelphia 1975: 872-874.

15. Hamdy MR, Nora AS. Parotid and mandibular salivary glands segmentation of the one humped dromedary camel (Camelus dromedarius). Int J Adv Res Biol Sci. 2017; 4(11): 31-41, doi: 10.22192/ijarbs.

16. Kimura J, Habata I, Endo H, et al. Histochemistry of complex carbohydrate in the major salivary glands of hoary bamboo rats (Rhizomys purinosus). Anat Histol Embryol. 1998; 27(3): 147-153, doi: 10.1111/j.1439-0264.1998. tb00172.x, indexed in Pubmed: 9652141.

17. Mahdi S, Khojasteh B, Delashoub M. Microscopic anatomy of the parotid and submandibular salivary glands in European hamster (Cricetus cricetus L. Int Res J App Basic Sci. 2012; 3(7): 1544-1548.

18. Miyazaki T, Tatsukawa S, Kitamura $\mathrm{H}$, et al. Morphological and functional changes of the rat parotid glandular cells by clipping and reopening the parotid duct, using HAM8 antibody. Anat Sci Int. 2008; 83(2): 89-95, doi: 10.1111/j.1447-073X.2007.00211.x, indexed in Pubmed: 18507618.

19. Paula F, Teshima TH, Hsieh R, et al. Overview of Human Salivary Glands: Highlights of Morphology and Developing Processes. Anat Rec (Hoboken). 2017; 300(7): 1180-1188, doi: 10.1002/ar.23569, indexed in Pubmed: 28192873.

20. Simawy MSH, Mahdi AA. Radiological comparative study of the mandibular salivary gland between adult male gazelle (subguttturosa) and sheep (awassi). Bas J Vet Res. 2019; 18(1): 122-133.

21. Singh $A D$, Jain RK, Pawan K. Topographic anatomy of buccal and labial glands in sheep. Haryana Vet. 2011; 50: 30-32.

22. Singh AD, Sasan S, ohn MA, et al. Gross and microscopic characterization of the parotid salivary gland of sheep. Indian Vet J. 2015; 92(1): 61-63.

23. Stevens A, Lowe SJ. Human Histology. 2nd ed. Mosby, Nottingham 1997: 188-189.

24. Tadjalli M, Dehghani SN, Basiri M. Sialography in dog: normal appearance. Veterinarski Arhiv. 2004; 74(3): 225-233.

25. Williams PL, Warwick R, Dyson M, Bannister LH. Gray's anatomy. 38th ed. Churchill Lvingtone, New York 1995: 1690-1691. 